\title{
LXR ligands induce apoptosis of EGFR-TKI-resistant human lung cancer cells in vitro by inhibiting Akt-NF-кB activation
}

\author{
SIWEN LIU ${ }^{1 *}$, HAIXIA CAO ${ }^{1 *}$, DAN CHEN ${ }^{1}$, SHAORONG YU $^{2}$, HUANHUAN SHA $^{2}$, JIANZHONG WU ${ }^{1}$, \\ RONG MA ${ }^{1}$, ZHUO WANG ${ }^{1}$, CHANGWEN JING ${ }^{1}$, JUNYING ZHANG ${ }^{1}$ and JIFENG FENG ${ }^{2}$ \\ ${ }^{1}$ Research Center for Clinical Oncology; ${ }^{2}$ Department of Oncology, Jiangsu Cancer Hospital, \\ Jiangsu Institute of Cancer Research, Nanjing Medical University \\ Affiliated Cancer Hospital, Nanjing, Jiangsu 210009, P.R. China \\ Received February 6, 2017; Accepted February 16, 2018
}

DOI: $10.3892 / \mathrm{ol} .2018 .8182$

\begin{abstract}
Epidermal growth factor receptor tyrosine kinase inhibitors (EGFR-TKIs) are efficient in treating patients with non-small cell lung cancer (NSCLC) harboring EGFR activating mutations. Unfortunately, nearly all patients ultimately acquire resistance to EGFR-TKI treatment. Liver X receptors (LXRs) can regulate tumor growth in various cancer cell lines. The present study indicated that LXR agonist combined with gefitinib weakened Akt-nuclear factor (NF)- $\kappa \mathrm{B}$ activation and inhibited the expression levels of apoptosis-related proteins in vitro. By contrast, LXR ligands alone exhibited no significant effect on gefitinib-resistant lung cells. In conclusion, the study provided evidence for the combination treatment of acquired TKI resistance in NSCLC.
\end{abstract}

\section{Introduction}

Lung cancer is the leading cause of cancer-related mortality worldwide (1), and non-small cell lung cancer (NSCLC) is the most common clinicopathological type. Although early diagnosis of lung cancer has developed in recent years, most patients are initially diagnosed with an advanced stage (2).

The epidermal growth factor receptor (EGFR) is a well characterized mutated oncogene in NSCLC with 10-20\% cases in Western countries and is predominantly associated with adenocarcinoma histology. EGFR-mutated tumors are dependent on EGFR signaling for proliferation and survival $(3,4)$. EGFR tyrosine kinase inhibitors (EGFR-TKIs) have shown dramatic therapeutic effects in patients with NSCLC harboring

Correspondence to: Mr. Jifeng Feng, Department of Oncology, Jiangsu Cancer Hospital, Jiangsu Institute of Cancer Research, Nanjing Medical University Affiliated Cancer Hospital, 42 Baiziting, Nanjing, Jiangsu 210009, P.R. China

E-mail: fengjifdoc@126.com

${ }^{*}$ Contributed equally

Key words: LXR ligands, gefitinib, drug resistance, lung cancer
EGFR-activating mutations. Based on the positive results of several phase III clinical trials, National Comprehensive Cancer Network (NCCN) has recommended EGFR-TKI as the standard first-line therapy in NSCLC patients with sensitive EGFR mutations $(5,6)$. However, nearly all patients eventually developed drug resistance after a median period of $~ 10$ months (7). Thus, innovative treatment strategies are urgently needed for increasing sensibility to EGFR-TKI and improving the survival of patients with NSCLC.

Recently, a number of nuclear receptor superfamily, including liver $\mathrm{X}$ receptors (LXRs), have been shown to mediate tumor proliferation and enhance chemotherapeutic efficacy (8-11). LXRs (LXR $\alpha / \mathrm{NR} 1 \mathrm{H} 3$ and LXR $\beta / \mathrm{NR} 1 \mathrm{H} 2$ ) can be activated by natural ligands, including oxysterols and synthetic agonists GW3965 (12). High level of LXR $\alpha$ expression can be found in liver, kidney, intestine, fat tissue and macrophages, whereas LXR $\beta$ expression is ubiquitous (13). Some studies have demonstrated that LXR ligands exhibited anti-cancer activities in a variety of cancer cell lines. For example, LXR ligands can suppress the proliferation of breast, ovarian, prostate, colon and leukemia cancer cells in vitro (14). Recently, a study has found that LXR ligands combined with gefitinib could suppress cell cycle progression by inhibiting cyclinD1 and cyclinB expression in NSCLC cells (15).

Based on these previous reports, the present study aimed to investigate the effects of synthetic LXR ligands (GW3965) on increasing sensibility of gefitinib-resistant NSCLC cell to EGFR-TKI and explored their potential mechanisms.

\section{Materials and methods}

Cell lines and reagents. Human NSCLC H827 cell line harboring the EGFR exon 19 deletion (Del E746-A750) was obtained from Shanghai Institutes for Biological Sciences, Chinese Academy of Cell Resource Center, and maintained in RPMI-1640 supplemented with 10\% FBS (Gibco; Thermo Fisher Scientific, Inc., Waltham, MA, USA) at $37^{\circ} \mathrm{C}$ with $5 \% \mathrm{CO}_{2}$ and at humidified atmosphere. Gefitinib (Iressa) was purchased from AstraZeneca, and GW3965 was purchased from Sigma-Aldrich (Merck KGaA, Darmstadt, Germany). Cells were treated with gefitinib and GW3965 in RPMI-1640 supplemented with 5\% FBS. Primary antibodies against MET, 


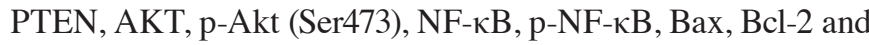
$\beta$-actin were obtained from cell signaling technology.

Generation of gefitinib-resistant H827 cells in vitro. To generate a resistant cell line, we exposed H827 cells to increasing concentrations of gefitinib according to previously described methods (16). The resistant H827 cells were passed 25 times in the absence of gefitinib and were found to maintain their resistance as confirmed by Cell Counting kit-8 (CCK-8; Dojindo, Kumamoto, Japan) assays. Six individual clones were isolated and all were confirmed independently to be resistant to gefitinib by CCK-8 assay. No significant change was observed in the sensitivity to gefitinib in parental cells during the period.

Cell proliferation assay. Cancer cells were seeded in 96-well plates and exposed to different doses of gefitinib alone, GW3965 alone, and both drugs for $96 \mathrm{~h}$. Each combination of cell line and drug concentration was set up in 5 replicate wells and repeated at least thrice. Cell proliferation was measured by the CCK-8 assay. $\mathrm{IC}_{50}$ values were determined by interpolation from the dose-response curves. Among the six gefitinib-resistant clones, we selected the most sensitive to LXR ligands for further study.

Sequencing of the EGFR gene. To determine the EGFR sequence of cells, DNA was extracted from each cell line using a QIA-amp DNA mini kit (Qiagen, Tokyo, Japan), and the exons encoding the intracellular domain (exons 18-21) were amplified by PCR. Primer sequences are shown in Table I (17). Sequencing was conducted using an $\mathrm{ABI} 3500$ sequencer (ABI).

Colony formation assay. Clonogenic survival assays were prepared according to literature (18). Briefly, H827-7-2 and H827-7-4 cells were seeded at a density of 600 cells/well in flat-bottomed 6-well plates. According to pre-experimental results, cells were treated with $2 \mathrm{ml}$ of gefitinib $(1 \mu \mathrm{M})$ alone, LXR ligands (GW3965, $1 \mu \mathrm{M}$ ) alone, and both drugs diluted with the medium to appropriate concentrations after $24 \mathrm{~h}$ of incubation. Then, cells were cultured for an additional 15 days, and subsequently stained with Giemsa. Experiments were performed forthrice.

Cell apoptosis analysis. H827-7-2 and H827-7-4 cells were seeded in 6-well plates $\left(2 \times 10^{4}\right.$ cells/well) for $12 \mathrm{~h}$ and treated with gefitinib $(5 \mu \mathrm{M})$ alone, LXR ligands (GW3965, $5 \mu \mathrm{M})$ alone, and both drugs for another $96 \mathrm{~h}$, and then cells were harvested and washed twice with ice-cold PBS. Annexin V-FITC/PI staining was used to detect apoptotic cells. Three individual experiments were conducted.

Quantitative PCR ( $q P C R$ ) analysis. Total RNA was isolated from H827-7-2 and H827-7-4 cells treated with GW3965 at different concentrations using TRIzol reagent (Invitrogen; Thermo Fisher Scientific, Inc.) according to the manufacturer's instructions and cDNA was synthesized with PrimeScript RT Master Mix and premix EX Taq ${ }^{\text {TM }}$ Probe qPCR Mix (Takara Bio, Dalian, China) on a 7300 Real-Time PCR system (Applied Biosystems; Thermo Fisher Scientific, Inc.) according to the manufacturer's instructions. Quantitative PCR was performed using SYBR Green PCR Mix (Roche, Mannheim, Germany). $\beta$-actin was used as an internal control to normalize the amount of total RNA in
Table I. Sequence of EGFR (at exons 18-21), $\beta$-actin, LXR $\alpha$, LXR $\beta$.

\begin{tabular}{ll}
\hline Primer name & \multicolumn{1}{c}{ Primer sequence 5' to 3' } \\
\hline EGFR18-F & AGCATGGTGAGGGCTGAGGTGAC \\
EGFR18-R & ATATACAGCTTGCAAGGACTCTGG \\
EGFR19-F & CCAGATCACTGGGCAGCATGTGGCACC \\
EGFR19-R & AGCAGGGTCTAGAGCAGAGCAGCTGCC \\
EGFR20-F & GATCGCATTCATGCGTCTTCACC \\
EGFR20-R & TTGCTATCCCAGGAGCGCAGACC \\
EGFR21-F & TCAGAGCCTGGCATGAACATGACCCTG \\
EGFR21-R & GGTCCCTGGTGTCAGGAAAATGCTGG \\
$\beta$-actin-F & GATGAGATTGGCATGGCTTT \\
$\beta$-actin-R & CACCTTCACCGTTCCAGTTT \\
LXR $\alpha-F$ & TCTGGAGACATCTCGGAGGTA \\
LXR $\alpha-R$ & GGCCCTGGAGAACTCGAAG \\
LXR $\beta-F$ & AGAAGATTCGGAAACAACAGCA \\
LXR $\beta-R$ & GCTGGATCATTAGTTCTTGAGCC \\
\hline
\end{tabular}

EGFR, epidermal growth factor receptor; F, forward; R, reverse; LXR, liver X receptor.

each sample. Primer sequences were summarized in Table I. The relative levels of gene expression were determined using the $\Delta \Delta \mathrm{Ct}$ method relative to internal control gene $\beta$-actin. All reactions were repeated thrice for each sample.

Moreover, qPCR was performed using premix EX Taq ${ }^{\mathrm{TM}}$ Probe qPCR Mix on a 7300 real-time PCR system. The copy number ratio of MET to GAPDH, a housekeeping gene, was calculated using a genomic DNA sample. The sequences of the Taqman probe and primers for MET and GAPDH were previously described (19). Quantification was based on standard curves from a serial dilution of normal human genomic DNA. All specimens were analyzed intriplicates.

Western blot analysis. Cells were lysed in RIPA buffer (Beyotime Institute of Biotechnology, Haimen, China). Proteins were separated on 10\% Bis-Tris Mini gels and transferred to a PVDF membrane. The primary antibodies used were AKT,

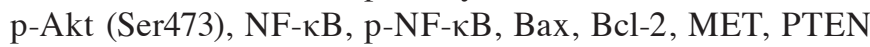
(1:1,000; Cell Signaling Technology, Inc., Danvers, MA, USA), and $\beta$-actin (1:1,000; Sigma-Aldrich). Proteins were detected with secondary antibodies (1:5,000; Immunology Consultanta Laboratory, Portland, OR, USA) and enhanced chemiluminescence solution (ECL; Beyotime Institute of Biotechnology).

Statistical analysis. Data were expressed as means \pm SD. Statistical analysis was conducted using one-way ANOVA and Student's t-test with Graphpad 5.0 and SPSS 13.0. P $<0.05$ was considered statistically significant.

\section{Results}

Effect of combined treatment of GW3965 and gefitinib. After establishing six monoclonal gefitinib-resistant H827 cell lines, we characterized their drug resistance indices through 
A

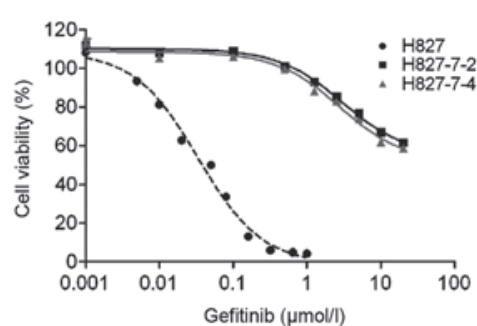

C

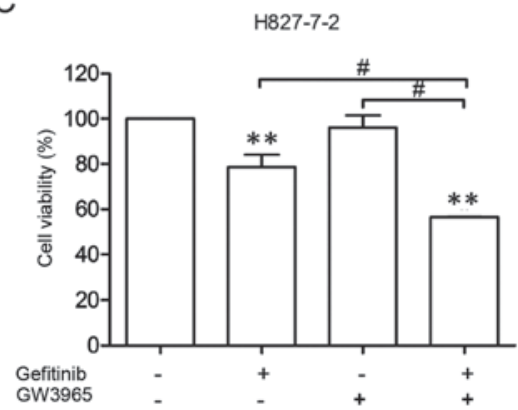

B
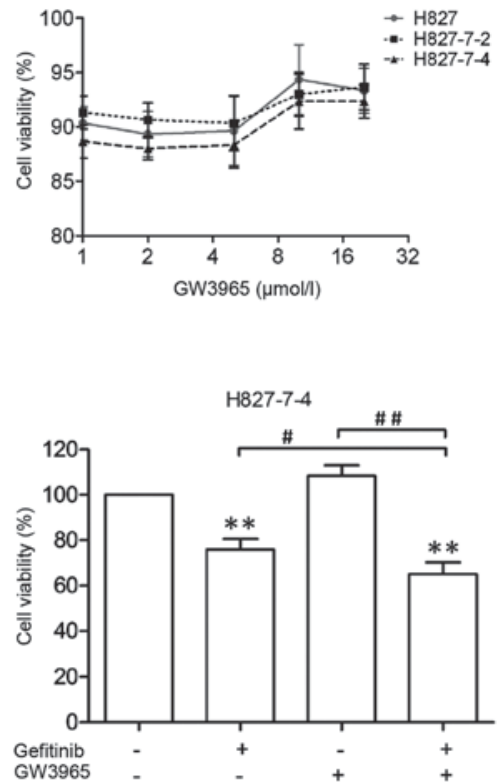

Figure 1. H827-7-2 and H827-7-4 cells resistant to gefitinib. (A and B) Cell lines were treated with the indicated doses of GW3965 or gefitinib for 96 h. The viability of cells was determined using the CCK-8 assay. (C) H827-7-2 and H827-7-4 cells were treated with gefitinib alone or combined with LXR ligands for 96 h. ${ }^{* *} \mathrm{P}<0.001$ compared with control; ${ }^{\#} \mathrm{P}<0.01,{ }^{\# \#} \mathrm{P}<0.001$ between one treatment alone. CCK-8, cell counting kit- 8 ; LXR, liver $\mathrm{X}$ receptor.

Table II. Lung cancer inhibitory concentration 50 values $\left(\mathrm{IC}_{50}\right)$ for treatment with gefitinib.

\begin{tabular}{lc}
\hline Human lung cancer cells & Gefitinib $\left(\mathrm{IC}_{50}{ }^{48 \mathrm{~h}}\right)$ \\
\hline H827 & $0.0401 \pm 0.042 \mu \mathrm{M}$ \\
H827-7-2 & $>20 \mu \mathrm{M}$ \\
H827-7-4 & $>20 \mu \mathrm{M}$ \\
\hline
\end{tabular}

$\mathrm{IC}_{50}$, half maximal inhibitory concentration.

cell proliferation assays. As illustrated in Table II, 300-fold increase was observed in $\mathrm{IC}_{50}$ for each monoclonal cell line compared with those of parental H827 cells (Fig. 1A).

We found that $5 \mu \mathrm{M}$ GW3965 had no inhibitory effects on the growth of TKI-resistant lung cancer cell lines and its monoclonal cell lines (Fig. 1B). Therefore, we continued using this concentration for further analysis. The amount of gefitinib $(5 \mu \mathrm{M})$, which was less than $50 \%$ of the inhibitory concentration $\left(\mathrm{IC}_{50}\right)$ had no significant effect on all monoclonal cells (Fig. 1A). Then, we explored the combinational therapeutic potential of GW3965 and gefitinib, in monoclonal cell lines. Combined treatment showed significant growth inhibitory proliferation compared with each drug alone in H827-7-2 and H827-7-4 cells (Fig. 1C). These data suggested that GW3965 may increase the sensitivity of NSCLC to EGFR-TKI. To exclude the mechanisms of acquired resistance, we conducted the DNA sequencing of EGFR at exons 18-21 and examined genetic alterations, including the levels of MET (20) and PTEN (21) and the well-known T790M mutation in these two monoclonal cells (Table I). T790M mutation at exon 20 was not observed in the H827-7-2 and H827-7-4 cells (Fig. 2A). The expression of PTEN was similar in both monoclonal cells, whereas MET was higher in H827-7-2 and H827-7-4 cells than in parental H827 cells (Fig. 2B and C).

LXR ligands increase gefitinib-induced apoptosis in H827-7-2 and H827-7-4 cells. We then analyzed the induction of apoptosis in the two monoclonal cells treated with GW3965 alone, gefitinib alone, or in combination. As shown in Fig. 3, flow cytometric analysis revealed that the percentage of apoptosis induced by gefitinib in H827-7-2 cells was $6.802 \%$. When GW3965 was added together with gefitinib, the percentage of apoptosis dramatically increased to $20.69 \%$. Similarly, the percentage of apoptosis induced by gefitinib increased from 8.88 to $22.06 \%$ after treatment with GW3965 in H827-7-4 cells (Fig. 3). Colony-forming assays revealed that GW3965 alone did not enhance the apoptosis of H827-7-2 and H827-7-4 cells, but the combination therapy significantly augmented apoptosis (Fig. 4A).

Furthermore, we examined the effect of GW3965 on apoptotic proteins. Cells were treated with gefitinib $(5 \mu \mathrm{M})$ alone, LXR ligand (GW3965, $5 \mu \mathrm{M}$ ) alone, or both drugs for $96 \mathrm{~h}$. Western blot analysis showed that gefitinib enhanced Bcl-2 expression and decreased Bax expression compared with that of the control. GW3965 treatment with gefitinib weakened the effect of cell apoptotic proteins compared with gefitinib alone (Fig. 4B). Overall, these in vitro data suggest that gefitinib resistant cells have a stress response to gefitinib, but GW3965 can reduce this stress response to gefitinib in the H827-7-2 and H827-7-4 cells. The combination of GW3965 with gefitinib resensitized the resistant cells to TKIs. Reduced stress response may be one of the important mechanisms underlying the synergistic effects of LXR ligands on gefitinib.

Effect of GW3965 on the transcriptional level of nuclear receptor LXR. As GW3965 activates LXR receptors, we then applied Quantitative PCR assay to confirm whether GW3965 affects the level of LXRs receptors ( $L X R \alpha$ and $L X R \beta)$ in 

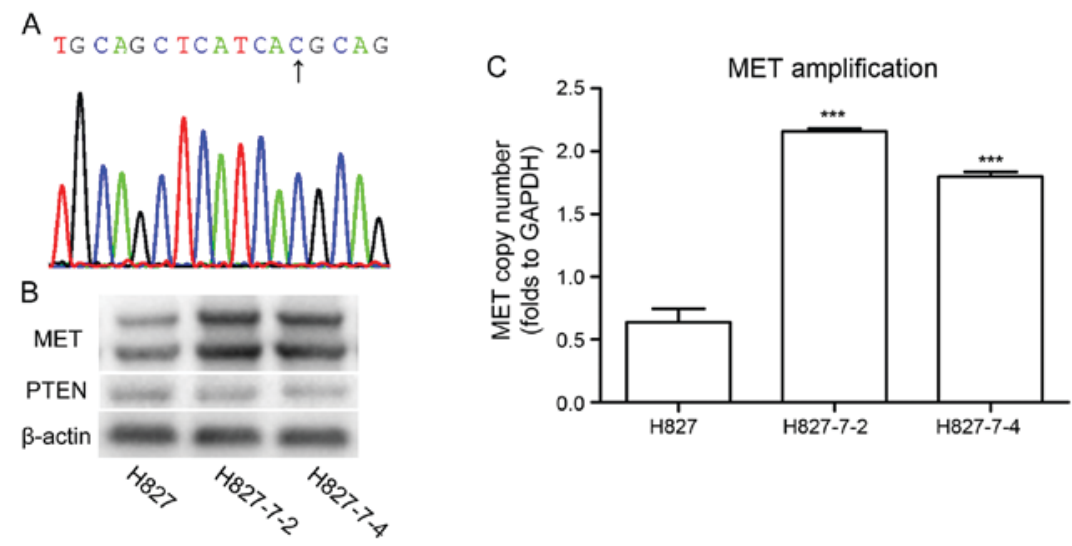

Figure 2. (A) T790M mutation was not observed in H827-7-2 and H827-7-4 cells by direct sequencing. (B) Western blot analysis was performed on H827: H827-7-2 and H827-7-4 cells to detect the expression levels of MET and PTEN. (C) The copy number ratio of MET to GAPDH, was calculated using a genomic DNA sample. ${ }^{* * *} \mathrm{P}<0.0001$ vs. H827.
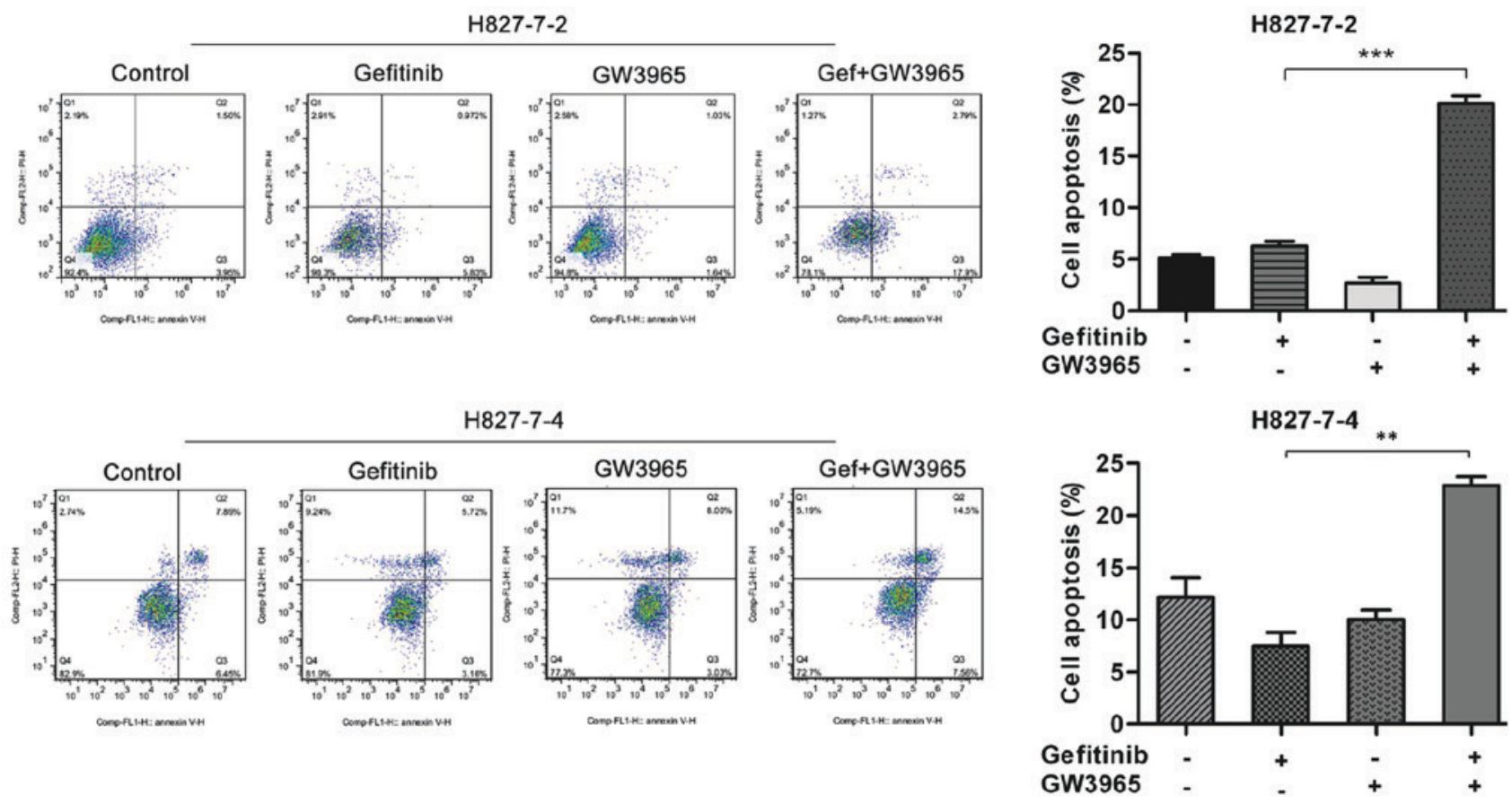

Figure 3. GW3965 $(5 \mu \mathrm{M})$ in combination with gefitinib $(5 \mu \mathrm{M})$ enhanced apoptosis of H827-7-2 and H827-7-4 cells. ${ }^{* *} \mathrm{P}<0.001$ and ${ }^{* * *} \mathrm{P}<0.0001$ vs. gefitinib treatment alone.

the cell nucleus. As shown in Fig. 5A, with the treatment of GW3965 in H827-7-2 and H827-7-4 cells, the expression level of $\mathrm{LXR} \alpha$ did not exhibit any differences, However, GW3965 increased the expression level of LXR $\beta$ distinctly at a higher dose (5 and $10 \mu \mathrm{M})$, whereas it had no effect at low dose $(1 \mu \mathrm{M})$.

GW3965 treatment with gefitinib influences the activation of $A K T-N F-\kappa B$. To further investigate the underlying mechanism of apoptosis introduced by GW3965 combined with gefitinib in H827-7-2 and H827-7-4 cells, these two cells were first treated with GW3965 (5 $\mu \mathrm{M})$ separately at various periods (0-96 h). The phosphorylation of AKT and NF- $\kappa \mathrm{B}$ was decreased after treatment with T0901317 for 96 h (Fig. 5B). Therefore, we analyzed the expression of EGFR and its downstream genes in two cells treated with gefitinib $(5 \mu \mathrm{M})$ alone, LXR ligands
(GW3965, $5 \mu \mathrm{M}$ ) alone or both drugs for $96 \mathrm{~h}$. As shown in Fig. 5C, the phosphorylation levels of AKT and NF- $\kappa \mathrm{B}$ when combined with GW3965 were downregulated compared with that of gefitinib alone.

\section{Discussion}

LXR is a ligand-dependent nuclear receptor. Previous study demonstrated that LXR had antiproliferative effects on cancer cells (22). Our results demonstrated that GW3965 exhibited no cytotoxicity in H827-7-2 and H827-7-4 cells. However, the proliferation rates of the two cells being treated with GW3965 combined with gefitinib were obviously inhibited when compared with that of gefitinib alone.

We found that GW3965 sensitized gefitinib in the two cells by inducing apoptosis and inhibiting colony formation. 
A
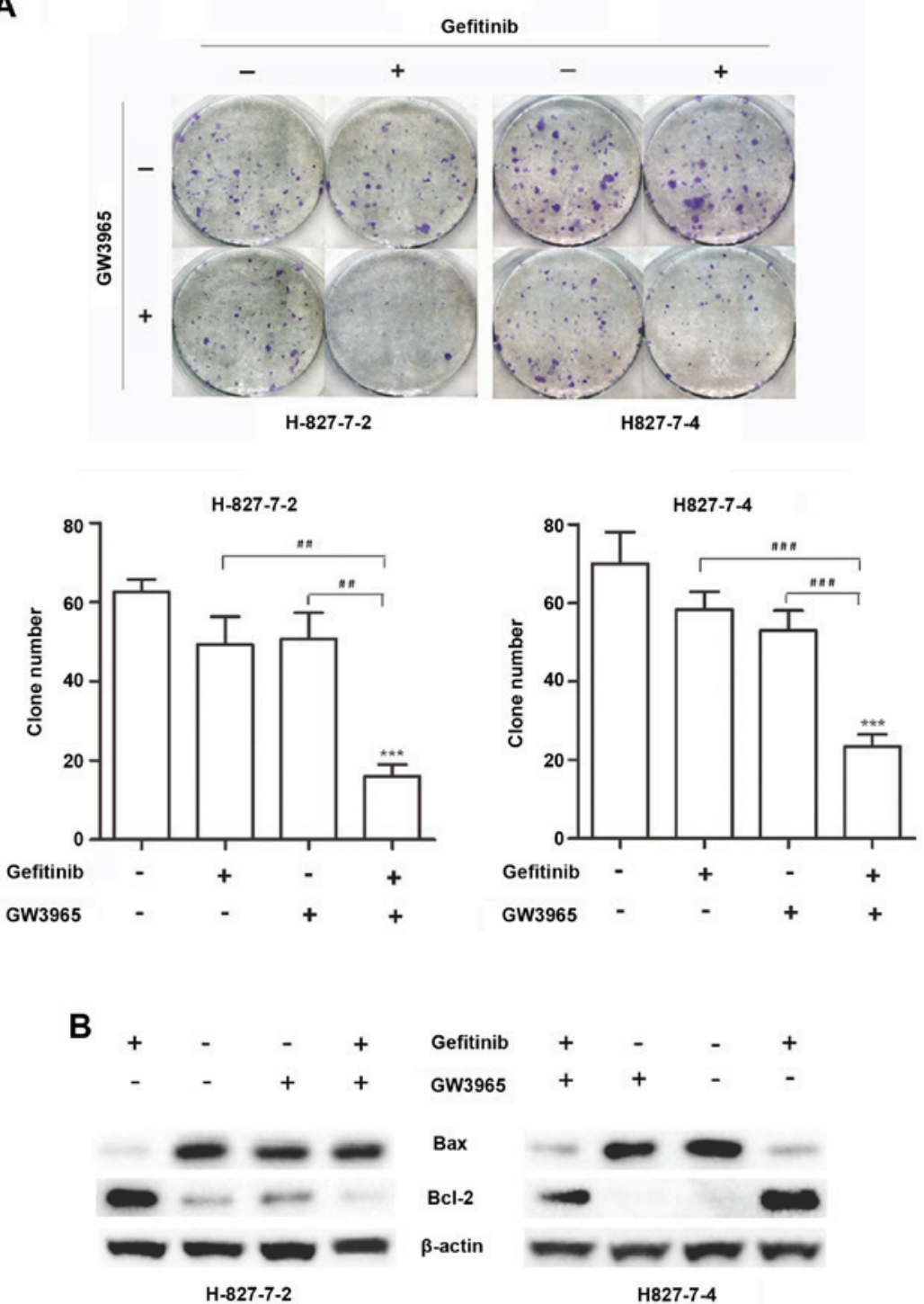

Figure 4. (A) Colony formation assays in H827-7-2 and H827-7-4 cells. ${ }^{* * *} \mathrm{P}<0.0001$ vs. untreated group; ${ }^{\# \#} \mathrm{P}<0.001$ and ${ }^{\# \# \#} \mathrm{P}<0.0001$ between one treatment alone. (B) Western blot analysis was performed to detect the expression levels of Bcl-2 and Bax with different treatments.

To further investigate whether GW3965 could affect cells apoptotic proteins, we detected the protein expression of Bcl-2 and Bax. Western blot analysis showed that gefitinib increased the expression level of $\mathrm{Bcl}-2$ and decreased the expression level of Bax compared with that in the control. These results further illustrated that lung cancer cells had been resistant to gefitinib (23). As expected, GW3965 alone did not change the expression level of cell apoptotic proteins compared with that in the control. Meanwhile, when GW3965 was combined with gefitinib, the expression levels of Bcl-2 decreased while Bax increased compared with that in gefitinib alone.

In addition, synthetic agonists including TO-901317 and GW3965, were biphasic activators of LXR $\alpha$ and LXR $\beta$ (24). Compared with endogenous ligands, synthetic agonists could activate LXR more effectively and generate stronger effect on the transcription of downstream target genes $(25,26)$. Colon cancer cell apoptosis could be induced by the LXR $\beta$-dependent pathway (27). However, LXR could be synergistic in human carcinomas owning to signaling interactions mediated through
LXR $\alpha$ (28). In this study, the expression level of LXR $\beta$ increased with higher dose of GW3965, prompting that LXR $\beta$ may be the primary subtype expressed in our experimental models.

Human NSCLCs with activating EGFR mutations showed an excellent response to treatment with EGFR-TKIs, including gefitinib and erlotinib. However, most patients with prolonged exposure to the drug developed relapse of cancer with drug resistance (29). Two principal mechanisms accounting for $\sim 50 \%$ of acquired resistance were secondary mutations of threonine-to-methionine substitution at amino acid position 790 (T790M) of EGFR and amplification of the N-methy 1-N0-nitro-N-nitroso-guanidine (MNNG) HOS-transforming gene (MET) oncogene (30-32). In this study, T790M mutation at exon 20 was not observed in the cells, but we found that the expression level of MET was higher in H827-7-2 and H827-7-4 cells than that in parental H827 cells, whereas PTEN had similar expression between two cell lines.

Various molecular mechanisms of acquired resistance to EGFR-TKIs in lung cancer were reactivation of EGFR 

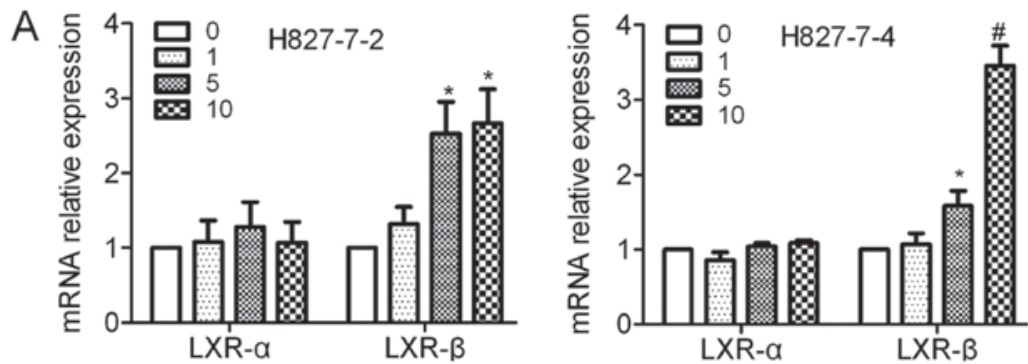

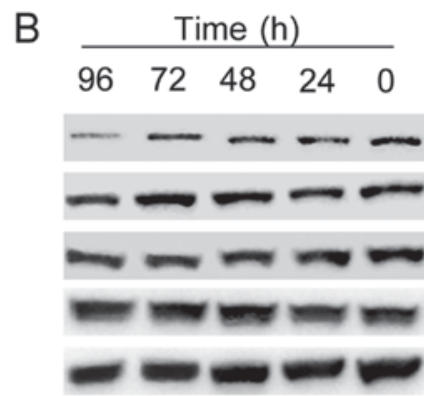

$\mathrm{H}-827-7-2$

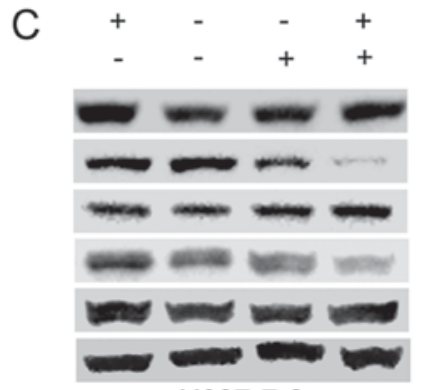

H827-7-2

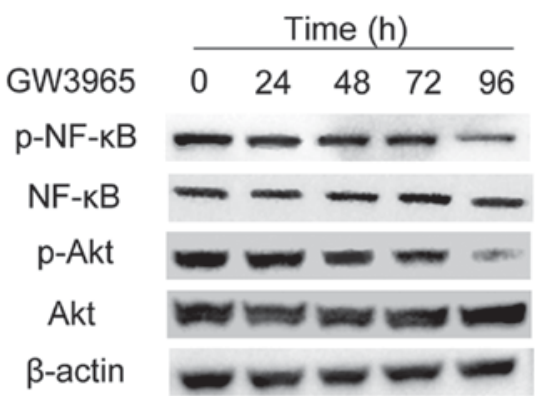

$\mathrm{H}-827-7-4$

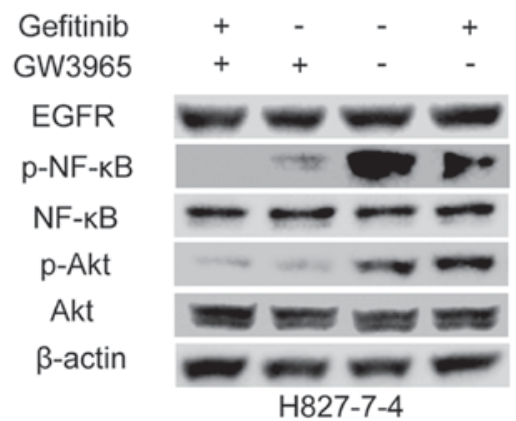

Figure 5. GW3965 sensitizes gefitinib by inhibiting Akt-NF- $\kappa$ B activation: (A) H827-7-2 and H827-7-4 cells were treated with increasing concentrations of LXR ligands. mRNA expression levels of LXR $\alpha$ and LXR $\beta$ were measured using the qPCR assay. ("P<0.01 and ${ }^{*} \mathrm{P}<0.001$ compared with control). (B) $\mathrm{H} 827-7-2$ and H827-7-4 cells were treated with GW3965 for different hour. The expression of AKT/p-AKT and NF- $\mathrm{B} / \mathrm{p}-\mathrm{NF}-\kappa \mathrm{B}$ were detected by western blot analysis. (C) H827-7-2 and H827-7-4 cells were treated with gefitinib alone or combined with LXR ligands for $96 \mathrm{~h}$. Western blot analysis was performed to detect the expressions of AKT, p-AKT, NF- $\mathrm{B}$ and $\mathrm{p}-\mathrm{NF}-\kappa \mathrm{B}$. LXR, liver X receptor.

downstream signaling pathways, especially Akt-NF- $\mathrm{B}$ signal pathway (33). MET amplification could lead to gefitinib resistance in lung cancer by activating ERBB3-phosphoinositide 3-kinase (PI3K)/Akt (34). NF- $\mathrm{B}$ was known to have a role in survival signaling and could promote the transcription of anti-apoptotic genes. Previous study found that inhibition of $\mathrm{NF}-\kappa \mathrm{B}$ enhanced apoptosis in EGFR-mutant lung cancer models (35). Furthermore, the inhibition of NF- $\mathrm{B}$ could enhance EGFR TKI-induced apoptosis (36). Previous studies demonstrated that the LXR agonist could inhibit activation of the EGFR-AKT-NF- $\kappa$ B pathway and also had a potential synergistic effect with EGFR-TKI treatment $(37,38)$. The phosphorylation of Akt and NF- $\kappa$ B reduced time dependently with GW3965 treatment in the two cells in our study. Thus, we hypothesized that the Akt-NF- $\kappa \mathrm{B}$ signaling pathway could be suppressed by the LXR agonist, so that it could sensitize gefitinib-resistant non-small cell lung cancer cells to gefitinib treatment. Our results proved this hypothesis and confirmed the inhibitory effect of the LXR agonist on the Akt-NF- $\kappa \mathrm{B}$ signaling pathway. The combination of gefitinib with GW3965 suppressed Akt-NF- $\mathrm{B}$ signaling pathway, which promoted cell apoptotsis and inhibited cell proliferation.

In conclusion, our results demonstrated that the LXR agonist GW3965 could effectively enhanced gefitinib-resistant cell sensitivity to gefitinib. In addition, the results suggested that the resensitization of H827-7-2 and H827-7-4 was achieved by the inhibited activation of Akt-NF- $\kappa \mathrm{B}$ pathway, which mediated by the LXR $\beta$ expression. Overall, these findings provided evidence for the combination treatment of acquired TKI resistance NSCLC.

\section{Acknowledgements}

This study was supported by the National Natural Science Foundation of China (no. 81372396) and the Natural Science Foundation of Jiangsu Province (nos. BK20141016 and BK20141017).

\section{Conflict of interest}

The authors declare that they have no conflict of interest. 


\section{References}

1. Jemal A, Bray F, Center MM, Ferlay J, Ward E and Forman D Global cancer statistics. CA Cancer J Clin 61: 69-90, 2011.

2. Jeong Y, Xie Y, Lee W, Bookout AL, Girard L, Raso G, Behrens C, Wistuba II, Gadzar AF, Minna JD and Mangelsdorf DJ: Research resource: Diagnostic and therapeutic potential of nuclear receptor expression in lung cancer. Mol Endocrinol 26: 1443-1454, 2012.

3. Mukohara T, Engelman JA, Hanna NH, Yeap BY, Kobayashi S, Lindeman N, Halmos B, Pearlberg J, Tsuchihashi Z, Cantley LC, et al: Differential effects of gefitinib and cetuximab on non-small-cell lung cancers bearing epidermal growth factor receptor mutations. J Natl Cancer Ins 97: 1185-1194, 2005.

4. Amann J, Kalyankrishna S, Massion PP, Ohm JE, Girard L, Shigematsu H, Peyton M, Juroske D, Huang Y, Stuart Salmon J, et al: Aberrant epidermal growth factor receptor signaling and enhanced sensitivity to EGFR inhibitors in lung cancer. Cancer Res 65: 226-235, 2005

5. Soria JC, Mok TS, Cappuzzo F and Jänne PA: EGFR-mutated oncogene-addicted non-small cell lung cancer: Current trends and future prospects. Cancer Treat Rev 38: 416-430, 2012.

6. Nguyen KS and Neal JW: First-line treatment of EGFR-mutant non-small-cell lung cancer: The role of erlotinib and other tyrosine kinase inhibitors. Biologics 6: 337-345, 2012.

7. Chong CR and Jänne PA: The quest to overcome resistance to EGFR-targeted therapies in cancer. Nature Med 19: 1389-1400, 2013.

8. Gong H, Guo P, Zhai Y, Zhou J, Uppal H, Jarzynka MJ, Song WC, Cheng SY and Xie W: Estrogen deprivation and inhibition of breast cancer growth in vivo through activation of the orphan nuclear receptor liver X receptor. Mol Endocrinol 21: 1781-1790, 2007.

9. Vedin LL, Lewandowski SA, Parini P, Gustafsson JA and Steffensen KR: The oxysterol receptor LXR inhibits proliferation of human breast cancer cells. Carcinogenesis 30: 575-579, 2009.

10. Villablanca EJ, Raccosta L, Zhou D, Fontana R, Maggioni D, Negro A, Sanvito F, Ponzoni M, Valentinis B, Bregni M, et al: Tumor-mediated liver $\mathrm{X}$ receptor-alpha activation inhibits $\mathrm{CC}$ chemokine receptor-7 expression on dendritic cells and dampens antitumor responses. Nat Med 16: 98-105, 2010.

11. Scoles DR, Xu X, Wang H, Tran H, Taylor-Harding B, Li A and Karlan BY: Liver X receptor agonist inhibits proliferation of ovarian carcinoma cells stimulated by oxidized low density lipoprotein. Gynecol Oncol 116: 109-116, 2010.

12. Lo Sasso G, Bovenga F, Murzilli S, Salvatore L, Di Tullio G, Martelli N, D'Orazio A, Rainaldi S, Vacca M, Mangia A, et al: Liver $X$ receptors inhibit proliferation of human colorectal cancer cells and growth of intestinal tumors in mice. Gastroenterology 144: 1497-1507, e1-e13, 2013.

13. Bischoff ED, Daige CL, Petrowski M, Dedman H, Pattison J, Juliano J, Li AC and Schulman IG: Non-redundant roles for LXRalpha and LXRbeta in atherosclerosis susceptibility in low density lipoprotein receptor knockout mice. J Lipid Res 51 900-906, 2010

14. Chuu CP and Lin HP: Antiproliferative effect of LXR agonists T0901317 and 22(R)-hydroxycholesterol on multiple human cancer cell lines. Anticancer Res 30: 3643-3648, 2010.

15. Wairagu PM, Park KH, Kim J, Choi JW, Kim HW, Yeh BI, Jung SH, Yong SJ and Jeong Y: Combined therapeutic potential of nuclear receptors with receptor tyrosine kinase inhibitors in lung cancer. Biochem Biophys Res Commun 447: 490-495, 2014.

16. Morgillo F, Cascone T, D'Aiuto E, Martinelli E, Troiani T, Saintigny P, De Palma R, Heymach JV, Berrino L, Tuccillo C and Ciardiello F: Antitumour efficacy of MEK inhibitors in human lung cancer cells and their derivatives with acquired resistance to different tyrosine kinase inhibitors. Br J Cancer 105: 382-392, 2011.

17. Pao W, Miller V, Zakowski M, Doherty J, Politi K, Sarkaria I, Singh B, Heelan R, Rusch V, Fulton L, et al: EGF receptor gene mutations are common in lung cancers from 'never smokers' and are associated with sensitivity of tumors to gefitinib and erlotinib. Proc Natl Acad Sci USA 101: 13306-13311, 2004.

18. Hu X, Xing L, Jiao Y, Xu J, Wang X, Han A and Yu J: BTG2 overexpression increases the radiosensitivity of breast cancer cells in vitro and in vivo. Oncology Res 20: 457-465, 2013.

19. Harada D, Takigawa N, Ochi N, Ninomiya T, Yasugi M, Kubo T, Takeda H, Ichihara E, Ohashi K, Takata S, et al: JAK2-related pathway induces acquired erlotinib resistance in lung cancer cells harboring an epidermal growth factor receptor-activating mutation. Cancer Sci 103: 1795-1802, 2012.
20. Nguyen KS, Kobayashi S and Costa DB: Acquired resistance to epidermal growth factor receptor tyrosine kinase inhibitors in non-small-cell lung cancers dependent on the epidermal growth factor receptor pathway. Clin Lung Cancer 10: 281-289, 2009

21. Suda K, Tomizawa K, Osada H, Maehara Y, Yatabe Y, Sekido Y and Mitsudomi T: Conversion from the 'oncogene addiction' to 'drug addiction' by intensive inhibition of the EGFR and MET in lung cancer with activating EGFR mutation. Lung Cancer 76: 292-299, 2012

22. Derangère V, Chevriaux A, Courtaut $F$, Bruchard $M$, Berger $H$, Chalmin F, Causse SZ, Limagne E, Végran F, Ladoire S, et al: Liver $X$ receptor $\beta$ activation induces pyroptosis of human and murine colon cancer cells. Cell Death Differ 21: 1914-1924, 2014.

23. Herr I and Debatin KM: Cellular stress response and apoptosis in cancer therapy. Blood 98: 2603-2614, 2001.

24. Wu Y, Yu DD, Yan DL, Hu Y, Chen D, Liu Y, Zhang HD, Yu SR, Cao HX and Feng JF: Liver X receptor as a drug target for the treatment of breast cancer. Anticancer Drugs 27: 373-382, 2016.

25. Mitro N, Vargas L, Romeo R, Koder A and Saez E: T0901317 is a potent PXR ligand: Implications for the biology ascribed to LXR. FEBS Lett 581: 1721-1726, 2007.

26. Collins JL, Fivush AM, Watson MA, Galardi CM, Lewis MC, Moore LB, Parks DJ, Wilson JG, Tippin TK, Binz JG, et al: Identification of a nonsteroidal liver $\mathrm{X}$ receptor agonist through parallel array synthesis of tertiary amines. J Med Chem 45: 1963-1966, 2002.

27. Courtaut F, Derangère V, Chevriaux A, Ladoire S, Cotte AK, Arnould L, Boidot R, Rialland M, Ghiringhelli F and Rébé C: Liver $\mathrm{X}$ receptor ligand cytotoxicity in colon cancer cells and not in normal colon epithelial cells depends on LXR $\beta$ subcellular localization. Oncotarget 6: 26651-26662, 2015.

28. Gabitova L, Restifo D, Gorin A, Manocha K, Handorf E, Yang DH, Cai KQ, Klein-Szanto AJ, Cunningham D, Kratz LE, et al: Endogenous sterol metabolites regulate growth of EGFR/KRAS-dependent tumors via LXR. Cell Rep 12: 1927-1938, 2015

29. Cadranel J, Ruppert AM, Beau-Faller M and Wislez M: Therapeutic strategy for advanced EGFR mutant non-small-cell lung carcinoma. Crit Rev Oncol Hematol 88: 477-493, 2013

30. Pao W, Miller VA, Politi KA, Riely GJ, Somwar R, Zakowski MF, Kris MG and Varmus H: Acquired resistance of lung adenocarcinomas to gefitinib or erlotinib is associated with a second mutation in the EGFR kinase domain. PLoS Med 2: e73, 2005.

31. Engelman JA and Jänne PA: Mechanisms of acquired resistance to epidermal growth factor receptor tyrosine kinase inhibitors in non-small cell lung cancer. Clin Cancer Res 14: 2895-2899, 2008.

32. Turke AB, Zejnullahu K, Wu YL, Song Y, Dias-Santagata D, Lifshits E, Toschi L, Rogers A, Mok T, Sequist L, et al: Preexistence and clonal selection of MET amplification in EGFR mutant NSCLC. Cancer Cell 17: 77-88, 2010.

33. Rosell R, Moran T, Queralt C, Porta R, Cardenal F, Camps C, Majem M, Lopez-Vivanco G, Isla D, Provencio M, et al: Screening for epidermal growth factor receptor mutations in lung cancer. N Engl J Med 361: 958-967, 2009.

34. Engelman JA, Zejnullahu K, Mitsudomi T, Song Y, Hyland C, Park JO, Lindeman N, Gale CM, Zhao X, Christensen J, et al: MET amplification leads to gefitinib resistance in lung cancer by activating ERBB3 signaling. Science 316: 1039-1043, 2007.

35. Bivona TG, Hieronymus H, Parker J, Chang K, Taron M, Rosell R, Moonsamy P, Dahlman K, Miller VA, Costa C, et al: FAS and NF- $\mathrm{KB}$ signalling modulate dependence of lung cancers on mutant EGFR. Nature 471: 523-526, 2011.

36. Sakuma Y, Yamazaki Y, Nakamura Y, Yoshihara M, Matsukuma S, Koizume S and Miyagi Y: NF- $\kappa \mathrm{B}$ signaling is activated and confers resistance to apoptosis in three-dimensionally cultured EGFR-mutant lung adenocarcinoma cells. Biochem Biophys Res Commun 423: 667-671, 2012.

37. Guo D, Reinitz F, Youssef M, Hong C, Nathanson D, Akhavan D, Kuga D, Amzajerdi AN, Soto H, Zhu S, et al: An LXR agonist promotes glioblastoma cell death through inhibition of an EGFR/AKT/SREBP-1/LDLR-dependent pathway. Cancer Discov 1: 442-456, 2011.

38. Cheng O, Ostrowski RP, Liu W and Zhang JH: Activation of liver $\mathrm{X}$ receptor reduces global ischemic brain injury by reduction of nuclear factor-kappaB. Neuroscience 166: 1101-1109, 2010.

This work is licensed under a Creative Commons Attribution-NonCommercial-NoDerivatives 4.0 International (CC BY-NC-ND 4.0) License. 